\title{
JOURNAL OF APPLIED PROBABILITY VOLUME 51 (2014): INDEX
}

Albrecher, H., Boxma, O. J. And Ivanovs, J. On simple ruin expressions in dependent Sparre

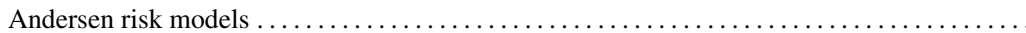

Alvarez, L. H. R. ANd Matomäki, P. Optimal stopping of the maximum process ............ Ano, K. see MATSUI, T.

Antzoulakos, D. L. see Boutsikas, M. V.

AristofF, D. Percolation of hard disks .

AsAdi, M. see Ashrafi, S.

Ashrafi, S. AND Asadi, M. Dynamic reliability modeling of three-state networks ............

Asmussen, S. AND Nielsen, B. F. Obituary: Marcel F. Neuts $1935-2014 \ldots \ldots \ldots \ldots \ldots \ldots \ldots \ldots$

— AND Foss, S. On exceedance times for some processes with dependent increments .........

BAHARIAN, G. AND JACOBSON, S. H. Limiting behavior of the target-dependent stochastic sequential assignment problem

Balakrishnan, N., Barmalzan, G. AND HAIDARI, A. Stochastic orderings and ageing properties of residual life lengths of live components in $(n-k+1)$-out-of- $n$ systems $\ldots \ldots \ldots \ldots \ldots$.

- And Volterman, W. On the signatures of ordered system lifetimes $\ldots \ldots \ldots \ldots \ldots \ldots \ldots$ see AND PARVARDEH, A.

BANDYOPADHYAY, A. AND SAJADI, F. On the nearest-neighbor algorithm for the mean-field traveling

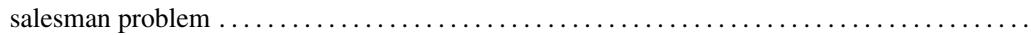

BAO, J. AND YUAN, C. Numerical approximation of stationary distributions for stochastic partial differential equations.

Barmalzan, G. see BALAKRishnan, N.

Beghin, L. AND Macci, C. Fractional discrete processes: compound and mixed Poisson representations

Bellini, F., Pellerey, F., Sgarra, C. and Sekeh, S. Y. Comparison results for GARCH processes

Biard, R. and Saussereau, B. Fractional Poisson process: long-range dependence and applications in ruin theory

Birget, J-C. see Hong, D.

BJörnberg, J. E. AND Broman, E. I. Coexistence and noncoexistence of Markovian viruses and

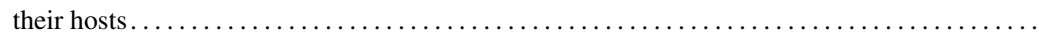

— Britton, T., Broman, E. I. And Natan, E. A stochastic model for virus growth in a cell

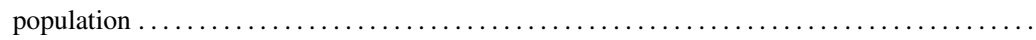

Borovkov, K., Decrouez, G. and Gilson, M. On stationary distributions of stochastic neural networks.

$191-208$

$599-612$

$837-857$

$483-491$ times and stopped sums in multistate exchangeable trials

BRADLEY, R. C. On a 'replicating character string' model

BritTon, T. see BJÖRnBERG, J. E.

Broman, E. I. see BJörnberg, J. E.

CAI, J. see ZHOU, M.

Campanino, M. And Petritis, D. Type transition of simple random walks on randomly directed

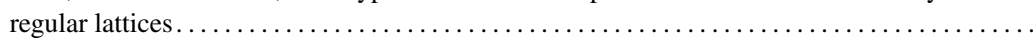

Cha, J. H. And Finkelstein, M. Stochastic modeling for environmental stress screening ........

Chen, A., LI, J., Chen, Y. And Zhou, D. Asymptotic behaviour of extinction probability of interacting branching collision processes 
- NG, K. W. AND Zhang, H. Uniqueness and decay properties of Markov branching processes

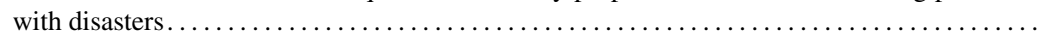

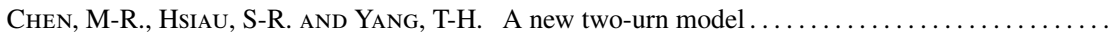

Chen, Y. see CHEN, A.

Christiansen, M. C. And Loperfido, N. Improved approximation of the sum of random vectors

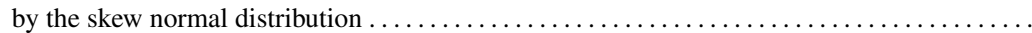

Cohen, S. N. Undiscounted Markov chain BSDEs to stopping times $\ldots \ldots \ldots \ldots \ldots \ldots \ldots \ldots$

DAI, D. Exact simulation for diffusion bridges: an adaptive approach $\ldots \ldots \ldots \ldots \ldots \ldots \ldots \ldots$

Decrouez, G. see Borovkov, K.

Duembgen, M. and Rogers, L. C. G. Investing and stopping $\ldots \ldots \ldots \ldots \ldots \ldots \ldots \ldots \ldots \ldots$

Ernst, P. A., Foster, D. P. And Shepp, L. A. On optimal retirement $\ldots \ldots \ldots \ldots \ldots \ldots \ldots \ldots \ldots$

Finkelstein, M. see Cha, J. H.

Finlay, R. And Seneta, E. Random fields with Pólya correlation structure $\ldots \ldots \ldots \ldots \ldots \ldots \ldots$

Foss, S. see Asmussen, S.

Foster, D. P. see ERnSt, P. A.

Freund, F. ANd Siri-JÉGousse, A. Minimal clade size in the Bolthausen-Sznitman coalescent ...

Fuchs, M., Hwang, H-K., ITOH, Y. AND Mahmoud, H. H. A binomial splitting process in connection

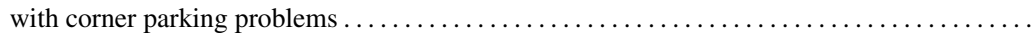

Gapeev, P. V. and Rodosthenous, N. Optimal stopping problems in diffusion-type models with

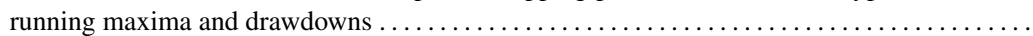

GaVA, R. J. AND SALOTti, D. Stopping probabilities for patterns in Markov chains.............

Geiger, B. C. AND Temmel, C. Lumpings of Markov chains, entropy rate preservation, and higher-

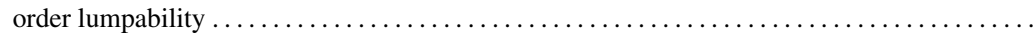

Gilson, M. see Borovkov, K.

Gnoatto, A. And Grasselli, M. The explicit Laplace transform for the Wishart process ........

Gordy, M. B. Finite-dimensional distributions of a square-root diffusion $\ldots \ldots \ldots \ldots \ldots \ldots \ldots$

Grace, A. W., Kroese, D. P. and Sandmann, W. Automated state-dependent importance sampling for Markov jump processes via sampling from the zero-variance distribution . . . . . . . . . .

Grasselli, M. see Gnoatto, A.

Gudmundsson, T. And Hult, H. Markov chain Monte Carlo for computing rare-event probabilities

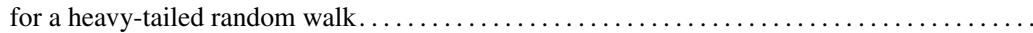

HAIDARI, A. see BALAKRISHNAN, N.

Hashorva, E. AND Ji, L. Approximation of passage times of $\gamma$-reflected processes with FBM input

He, H. And Rugang, M. A. Limit theorems for continuous-time branching flows ...........

Hitczenko, P. and Letac, G. Dirichlet and quasi-Bernoulli laws for perpetuities .............

Hong, D., Man, S., Birget, J-C. And Lun, D. S. A wavelet-based almost-sure uniform approximation of fractional Brownian motion with a parallel algorithm. $\ldots \ldots \ldots \ldots \ldots$.

Howlett, P., Pearce, C. and Piantadosi, J. A new look at urban water storage in a series of

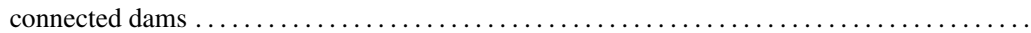

HSIAU, S-R. see CHEN, M-R.

HuA, L., JoE, H. AND Li, H. Relations between hidden regular variation and the tail order of copulas

Huber, M. AND SchotT, S. Random construction of interpolating sets for high-dimensional integration

Hult, H. see Gudmundsson, T.

HwANG, H-K. see Fuchs, M.

IтоH, Y see Fuchs, M.

Ivanovs, J. Potential measures of one-sided Markov additive processes with reflecting and

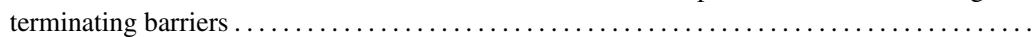
see Albrecher, $\mathrm{H}$.

IYER, S. see VAZE, R.

JACOBSON, S. H. see BAHARIAN, G.

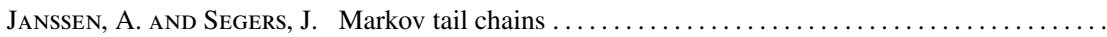

Ji, L. see HASHORVA, E.

Joe, H. see HuA, L.

KLimmeK, M Parameter dependent optimal thresholds, indifference levels and inverse optimal

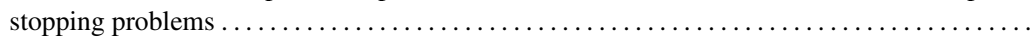

Konstantinides, D. G. see YAnG, Y.

613-624

$590-598$

$466-482$

262-281

346-358

898-909

333-345

1037-1050

657-668

971-989

799-817

287-292

114-1132

640-656

930-942

$741-755$

359-376

713-726

317-332

$400-416$

1-18

118-135

$37-57$

92-105

1133-1153

492-511 
Kontorovich, A. AND WeIss, R. Uniform Chernoff and Dvoretzky-Kiefer-Wolfowitz-type

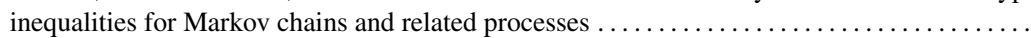

Kroese, D. P. see Grace, A. W.

Kumari, J. V. see VASUdEVA, R.

LAM, H-C. Quenched central limit theorem for reversible random walk in random environment on $\mathbb{Z}$

ŁatusZyŃski, K. AND Rosenthal, J. S. The containment condition and AdapFail algorithms ....

LE, V. Coalescence times for the Bienaymé-Galton-Watson process $\ldots \ldots \ldots \ldots \ldots \ldots \ldots \ldots$.

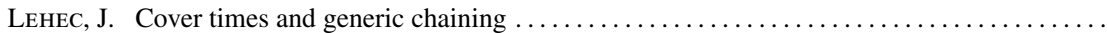

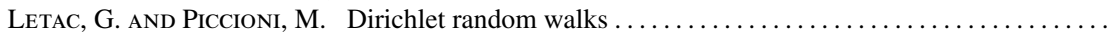

- see Hitczenko, P.

LI, H. see HuA, L.

LI, J. see CHEN, A.

LINDBERG, C. Pairs trading with opportunity cost

LIU, J. AND ZHOU, X. Extreme analysis of a random ordinary differential equation............

Loperfido, N. see Christiansen, M. C.

LOPES, F. Invariant bipartite random graphs on $\mathbb{R}^{d}$

LóPEz, O. AND RATANOV, N. On the asymmetric telegraph processes $\ldots \ldots \ldots \ldots \ldots \ldots \ldots \ldots$

Louis, P-Y. see Pra, P. D.

Lun, D. S. see Hong, D.

LUO, S. Stochastic Brownian game of absolute dominance . .

$769-779$

$569-589$

MACCI, C. see BEgHIN, L.

Mahmoud, H. H. see Fuchs, M.

MAN, S. see Hong, D.

Martínez, S., San Martín, J. And Villemonais, D. Existence and uniqueness of a quasistationary distribution for Markov processes with fast return from infinity $\ldots \ldots \ldots \ldots \ldots \ldots \ldots \ldots$

Matomäкi, P. see Alvarez, L. H. R

Matsui, T. AND ANO, K. A note on a lower bound for the multiplicative odds theorem of optimal

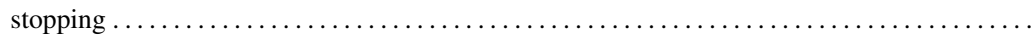

McKinlay, S. A characterisation of transient random walks on stochastic matrices with Dirichlet distributed limits

$1051-1064$

$1189-1195$

209-218

247-261

$1081-1099$

McVinish, R. AND Pollett P. K. The limiting behaviour of Hanski's incidence function

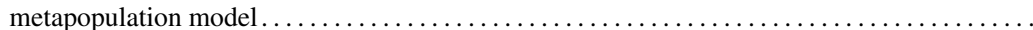

Minelli, I. G. see Pra, P. D.

NATAN, E. see BJÖRNBERG, J. E.

NAtvig, B. On the deterioration of nonrepairable multistate strongly coherent systems .........

Nielsen, B. F. see Asmussen, S.

NG, K. W. see CHEN, A.

Olofsson, P. And Sindi, S. S. A Crump-Mode-Jagers branching process model of prion loss in

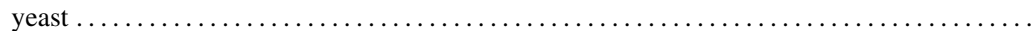

Parvardeh, A. And Balakrishnan, N. On the conditional residual life and inactivity time of

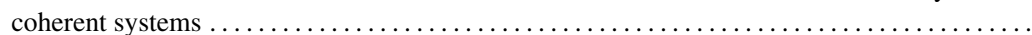

Pearce, C. see Howlett, P.

Pellerey, F. see Bellini, F.

Percus, J. K. see Percus O. E.

Percus O. E. And Percus, J. K. The maximum of a symmetric next neighbor walk on the nonnegative integers.

Petritis, D. see Campanino, M.

Piccioni, M. see Letac, G.

Piantadosi, J. see Howlett, P.

Pimentel, L. P. R. On the location of the maximum of a continuous stochastic process .........

Pollett P. K. see McVinish, R.

Pra, P. D., Louis, P-Y. AND Minelli, I. G. Synchronization via interacting reinforcement........

Rakitzis, A. C. see BoutsiKas, M. V.

Ratanov, N. see López, O.

RAVI, S. see VASUDEVA, R.

RENAUd, J-F. On the time spent in the red by a refracted Lévy risk process $\ldots \ldots \ldots \ldots \ldots \ldots \ldots$

Robert, C. Y. On the De Vylder and Goovaerts conjecture about ruin for equalized claims ....... 
Rodosthenous, N. see Gapeev, P. V.

Rogers, L. C. G. see Duembgen, M.

Rosenthal, J. S. see ŁATUSZyŃsKi, K.

Ross, S. M. Simulation analysis of system life when component lives are determined by a marked

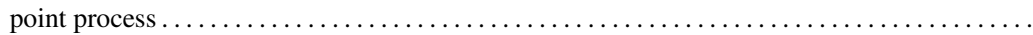

- Optimal server selection in a queueing loss model with heterogeneous exponential servers,

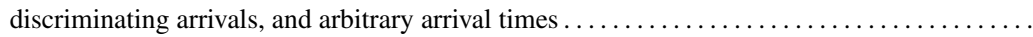

RoyChoudhury, A. Identifiability of a coalescent-based population tree model.............

Rugang, M. A. see He, H.

Ruggiero, M. Species dynamics in the two-parameter Poisson-Dirichlet diffusion model

SaJadi, F. see Bandyopadhyay, A.

SAlotTi, D. see GAVA, R. J.

San Martín, J. see Martínez, S.

Sandmann, W. see Grace, A. W.

Saussereau, B. see Biard, R.

Schott, S. see Huber, M.

SEgERS, J. see JANSSEN, A.

SEKEH, S. Y. see Bellini, F.

Seneta, E. see Finlay, R.

Sgarra, C. see Bellini, F.

Shepr, L. A. see Ernst, P. A.

Simatos, F. Coupling limit order books and branching random walks

Sindi, S. S. see OlofsSon, P.

Siri-JÉgousse, A. see Freund, F.

Temmel, C. see Geiger, B. C.

VasudeVa, R., Kumari, J. V. ANd Ravi, S. On the asymptotic behaviour of extremes and near maxima of random observations from the general error distributions $\ldots \ldots \ldots \ldots \ldots \ldots \ldots$

VAZE, R. AND IYER, S. Percolation on the information-theoretically secure signal to interference ratio graph

VERGARA, V. Asymptotic behaviour of the time-fractional telegraph equation .

Villemonais, D. see Martínez, S.

Volterman, W. see BALAKRISHNAN, N.

WANG, K. see YANG, Y.

WANG, R. Asymptotic bounds for the distribution of the sum of dependent random variables......

Weiss, R. see Kontorovich, A.

YANG, T-H. see CHEN, M-R.

YANG, Y., WANG, K. AND Konstantinides, D. G. Uniform asymptotics for discounted aggregate claims in dependent risk models . . . . . . . . . . . . . . . . . . . . . . . . . . . . .

YUAN, C. see BAO, J.

ZHANG, H. see CHEN, A.

ZHANG, Y. Average optimality for continuous-time Markov decision processes under weak continuity conditions

ZHou, D. see CHEN, A.

Zhou, M. AND CAI, J. Optimal dynamic risk control for insurers with state-dependent income ....

Zhou, X. see LiU, J.

ZHU, L. Limit theorems for a Cox-Ingersoll-Ross process with Hawkes jumps ... 